\title{
Andrei Tarkovsky’s Imaginary: Word, Silence, and Meaning
}

\author{
Mário Avelar \\ Universidade Aberta, Lisbon, Portugal
}

\begin{abstract}
Andrei Tarkovsky's cinematic signature bespeaks of a metaphysical dimension which is inseparable of an unwavering dialogue between poetic word and image. In three of his movies—Mirror (1975), Stalker (1979) and Nostalghia (1983) — the Russian director helps to build this dimension with the insertion of his father's Arsenii poems. Although these poems may develop a pivotal dynamic in Mirror, even when they may seem to have a marginal existence, such as they do in Stalker and Nostalghia, their function is far from assuming a decorative status. Anchored in Tarkovsky's notion of organic movie in mind, as he developed it in his book Sculpting in Time, and in William Desmond's concept of in-betweeness, as he conceived it in Art, Origins, Otherness-Between Philosophy and Art, this article challenges the notion of structural relevance, and shows how the alleged marginal presence of Arseni's words contribute to create a space of metaphysical in-betweeness that lies at the core of the movie's spiritual dimension.
\end{abstract}

Keywords: in-betweeness, journey, metaphysic, organic, poetry, stalker, word

\section{Introduction}

Poetry plays a relevant role in Andrei Tarkovsky’s filmic dialogue between word and image. Among the poets who echo in the Russian director's movies, his father Arsenii stands out with poems in Mirror (1975), Stalker (1979) and Nostalghia (1983). Film critic Kitty Hunter Blair claims that these poems operate on different levels: as key element to the concept and structure of Mirror, and as quotations without structural relevance in Stalker and Nostalghia.

In this article, I ponder on the poem's function in Stalker in order to challenge the notion of structural relevance, the basic theoretical ground on which this diagnostic stands. With Tarkovsky's assumption of organic movie in mind, as he developed it in his book Sculpting in Time, I show how the alleged marginal presence of Arseni's words contribute to create a space of metaphysical in-betweeness that helps to build and unfold the movie's spiritual dimension.

\section{In-betweeness, a Metaphysical Soil}

My analysis follows the notion and the epistemological relevance of in-betweeness, as William Desmond conceived of it in Art, Origins, Otherness-Between Philosophy and Art. The Irish philosopher anchored his approach in the context of a metaxological philosophy, "one attuned to our intermediate condition, our 'being between'... with a memory longer than the 'thought-bites' of immediate relevance, ... with a thoughtfulness 
lucid about the elemental perplexities of our condition of being, perplexities that recur as long as we are what we are” (Desmond, 2003, pp. x-xi). These so-called “elemental perplexities” (Desmond, 2003, p. xi) somehow stand as original reminders of our historical essence both as individuals-hence the idiosyncratic presence and symbolical function of certain signs - and as historical beings, with our specific relationships with a collective timeline-we may designate it identity.

One of the concepts Desmond rescues with this perspective in mind is philology, since:

Philology gives us an instructive lesson concerning the other in logos itself. It too troubles any totalizing of the principle of sufficient reason. Words are overdetermined; they mean more than they say explicitly, carry around within themselves unacknowledged origins. Words are excess: they express reserves of meaning but also reserve recesses. (Desmond, 2003, p. 176)

One cannot help reminding Ralph Waldo Emerson's statement in his essay “The Poet”: "Language is fossil poetry” (Emerson, 1982, p. 271).

Following this line of thought we eventually reach the conclusion that words may function as reservoirs of meaning and as interfaces of communication (Desmond, 2003, p. 36) that help us to surpass circumstances of time and place, and to fully understand our place in the world. Being, in his renewed contact with the Other, stands thus at the core of an ongoing dialogue with the Real Presences that the past has bequeathed us. Art emerges then as a powerful mediator at this level; or, as Andrei Tarkovsky put it in Sculpting in Time: “... art could almost be said to be religious in that it is inspired by commitment to a higher goal” (Tarkovsky, 1987, p. 168).

\section{Andrei Tarkovsky's Notion of Organic Form}

Art's function as mediator, as conceived by Tarkovsky and in consonance with Desmond's argument in Art, Origins, Otherness-Between Philosophy and Art, demands it to be anchored in a radical inner coherence, the coherence of a microcosm, since here the sign simultaneously acts on a syntagmatic and on a paradigmatic level. One may argue that this happens in every narrative. Yet syntagmatic relations stand out because we usually confine the structural relevance of a sign to its function in narrative dynamics.

Tarkovsky's notion of organic form definitely challenges this reading, when he claims that "[t]he true artistic image is always based on an organic link between idea and form” (Tarkovsky, 1987, p. 26). We infer from this statement that organic form implies a relationship in a wider context, a context that doesn't confine the relationships among signs to an inner structural soil, but that requires instead a dialogue with elements that stand beyond the microcosm. And it is here in this hors-champ, in this fluid space of in-betweeness that may lie the answer to the Russian director's aesthetics.

In his November 20th, 1981, article in the French newspaper Libération, Serge Daney sharply diagnosed the relevance of the organic principle in Stalker when he claimed that: "In Stalker the elements have an organic presence: water, dew and puddles dampen the soil and eat away at the ruins” (Daney, 1981, p. 1). The atmosphere thus stands out as key enhancer of meaning. And here the paradigm, the link between the narrative and the other, acquires a radical relevance; Tarkovsky claims this to be a poetical dimension: "Through poetic connections feeling is heightened and the spectator is made more active” (Tarkovsky, 1987, p. 20). 
If, on the one hand poetic connection summons both a syntagmatic and a paradigmatic approach, a space in-between, on the other hand it challenges the notion of spectator. In my view, beholder is the concept that meets the director's demand of our involvement in the movie's atmosphere, and hopefully in its impact on the visual and spiritual experience that takes place in the movie theatre. Viewing also implies the dynamic attitude of contemplation; hence the radical connection between time within the frame- - "the 'pressure of time' within each shot” (Marks, 1998, p. 149) that echoes Deleuze'scristal-image (Deleuze, 1985, pp. 95-106) —and time as concealed memory (cited from Casadei, 2012, p. 50)—-the inner experience—-that silently unfolds all along the character's journey.

Tarkovsky claims that "... even though outwardly their journey seems to end in fiasco, in fact each of the protagonists acquires something of inestimable value: faith” (Tarkovsky, 1987, p. 199). With this emphasis on faith as the ultimate achievement, the artist highlights the importance of hope, thusquestioning Serge Daney's dysphoric reading of an in-betweeness status: "These transitory people [Stalkers] live a miserable existence between two worlds” (Daney, 1981, p. 1). Alverto Ruiz de Samaniegoemphasizes Tarkovsky's denial of this desolate diagnostic when he sharply recollects the symbolical implications of the stalker's status:his is the path of those that move forward into unknown territory (Samaniego, 2015, p. 182). This diagnosticis further confirmed by the Russian director when he recalls that “... the hero goes through moments of despair when his faith is shaken; but every time he comes to a renewed sense of his vocation to serve people who have lost their hopes and illusions” (Tarkovsky, 1987, p. 193).

\section{Stalker-an In-betweeness Poetic Progress}

The protagonist — the Stalker, and the other main characters—-the writer and the Scientist, coincide in their journey with Tarkovsky's aesthetic pursuit and metaphysical progress:

The striving for perfection leads an artist to make spiritual discoveries, to exert the utmost moral effort. Aspiration towards the absolute is the moving force in the development of mankind. For me the idea of realism in art is linked with that force. Art is realistic when it strives to express an ethical ideal. Realism is a striving for the truth, and truth is always beautiful. Here the aesthetics coincides with the ethical. (Tarkovsky, 1987, p. 113)

It is thus in the wider context of an artistic pursuit which simultaneously implies a metaphysical journey, that the fleeting poetic presence acquires a special relevance; a relevance emphasised by the fact that it is the protagonist himself who recites Arseni Tarkovsky’s poem “Now summer is gone” to his journey companions.

In her invaluable notes, Katy Hunter Blair writes that Arsenii's poem, written in 1968 on a visit to Lithuania, "has been set to music several times, sometimes changing the meaning, much to the indignation of the poet's friends. He himself was usually unconcerned: 'Never mind, it's not important, let them sing it'” (Blair, 2015, p. 217). Yet its meaning in the movie's context, with its emphasis on a fluid perception of a time both past and future to come, on a state where memory emerges as remnant of a euphoric instant, is far from being irrelevant:

Now summer is gone

It might never have been.

It's warm in the sun,

And yet surely there's more. 


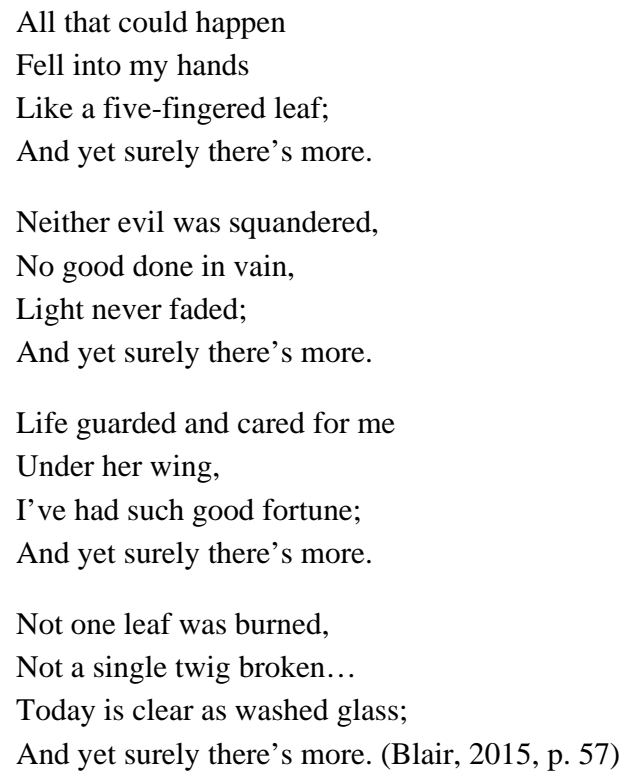

The line that keeps coming back like an echo at the end of each stanza reverberates inside and outside the narrative, since it reminds the Writer and the Scientist, the Stalker's journey companions, and the beholder too, that something lies beyond this material world. Hopefully the "Room of desires", prevails ahead as reminder that something is at stake in the Stalker's narrative, as Daneyhas pointed out (Daney, 2015, p. 188).

Thus, a lesson emerges; a lesson that doesn't confine itself to the story, and that also lingers in the beholder's mind when he leaves the movie theater. As Blair rightly emphasizes, the protagonist recites the poem "in a state of physical and mental exhaustion, ... Light alternates with shadow and fades at the line about good fortune, then the screen brightens for the last stanza” (Blair, 2015, p. 58). The effort lies at the core of what is supposed to be a single unified event: journey, artistic experience and spiritual quest.

Nothing comes easy in this process, and as the organic concept and structure denotes, words are not mere communicational circumstances. The choice of "Now summer is gone" somehow clarifies their organic relevance.

The film screenplay reveals that another Arsenii'spoem was initially chosen to be read by the protagonist, "Still from above on to time and space:"

Still from above on to time and space

We shall lay the palms of our hands,

But shall come to know that the star of need

Is most prized in the royal crown,

The star of want, of futility,

And fretting about our sad bread-

Accounts with alien galaxies

We shall clear on our motherly earth. (Blair, 2015, p. 159)

In Blair's notes to her translation of Arsenii's poems, she points out that "[b]y changing to 'Now summer is gone' the director moved from the themes of strength in weakness and human beings as children of the earth, both of which are demonstrated in the person of the Stalker, to a more personal, and more open-ended, expression of 
spiritual search” (Blair, 2015, pp. 217-218). In this open-endedness lies a crucial feature, since the beholder may identify himself with this search. Besides he may analyze symbolical details under the lens of his specific biographical circumstances.

Although they don't function as key structural transformers enhancing new narrative circumstances, words are a constant whisper of meaning that the beholder may identify. Allow me to point out some examples: when the Stalker prays, he summons words from Tao Te Ching; he repeats to himself the Gospel passage about the meeting on the road to Emmaus; even in his dreams he imagines his wife reading aloud from the Book of Revelation (Blair, 2015, p. 59). The philological dimension highlights the timelessness of the wisdom unfolding in those words.

Their relevance is also testified at the end of the film by the Stalker's wife voiceover reading of Fedor Tiuchev's poem "How I love your eyes", one of Arsenii's favourite poems. Thus, the protagonist, the artist and his father—art and life, film and biography—somehow juxtapose, in a radical spiritual and aesthetic symbiosis:

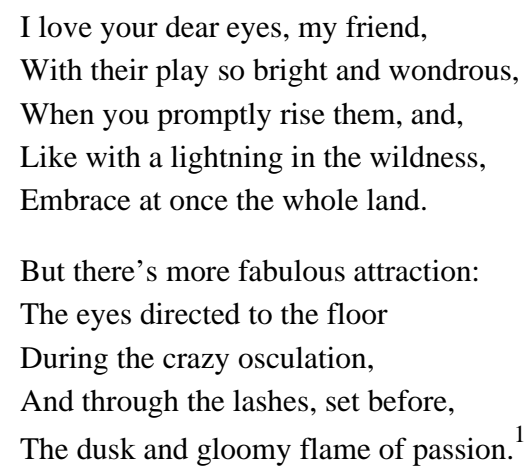

Another dimension, the one of cinematic grammar, emerges in these lines. The poem actually functions as a movie script with specific scenic information and requests. Alberto Ruiz de Samaniego acknowledges as a cinematic signature of Tarkovsky's movies the fact that the camera, that also claims a stalker status (Samaniego, 2015, p. 188), avoids the line of the horizon (p. 192). With its focus on the eyes, and with its scenic directions- “you promptly rise them", "Embrace the whole land", the poem somehow replaces opening the frame into the wider spaces of the personal innerscape, the place where the dramatic action eventually takes place. Then, only then revelation actually happens and the poem reminds the beholder of its structural relevance in an organic continuum.

\section{Conclusion}

Poetry thus plays a determinant role in the Stalker's progress in the fluid soil of the Zone, when he dives deep among the remains of the past and confronts his own personal ghosts in atmosphere that somehow echoes Georg Trakl's poetry (Samaniego, 2015, p. 182), in his struggle to achieve the ultimate truth supposedly concealed in the Room, since it helps him to unveil and understand his own metaphysical search. Besides, it reminds how close he is to our own inner searches, and how right Serge Daney was when he proclaimed: “Always remember that in 'metaphysical,' even in Russian, you have 'physical.””

\footnotetext{
${ }^{1}$ Alexandra Demidova (Producer), Andrei Tarkovsky (Director) (1979). Stalker. Soviet Union.
} 


\section{References}

Blair, K. H. (2015). Poetry and film—Artistic kinship between Arsenii and Andrei. London: Tate.

Casadei, E. B. (2012). Memória, Duração e Pulsão em Tarkovsky e Soderbergh:Em Torno do Filme Solaris (Memory, Duration, and Drive in Tarkovsky and Soderbergh: On Solaris). Revista Novos Olhares, 1(1), 47-57.

Daney, S. (1981). Stalker. La Zone de Tarkovski (Stalker. Tarkovski’s Zone) (F. Matcha \& S. Erickson, Trans.). Libération. November 20th.

Daney, S. (2015). O cinema que faz escrever-Textos críticos (The cinema that enhances writing-Critical Texts) (J. Frazão \& A. Eliseu,Trans.). Lisboa: Angelus Novus.

Deleuze, G. (1983). Cinéma I. L’Image-Mouvement (Cinema I-Image-Movement). Paris: Les Éditions du Miinuit.

Deleuze, G. (1985). Cinema 2. A Imagem-Tempo (Cinema 2-Image-Time) (R. Godinho, Trans.). Lisboa: Assírio \& Alvim.

Demidova, A. (Producer), Tarkovsky, A. (Director). (1979). Stalker. Soviet Union.

Desmond, W. (2003). Art, origins, otherness-Between philosophy and art. Albany: State University of New York Press.

Emerson, R. W. (1982). Selected essays. Harmondsworth: Penguin.

Marks, J. (1998). Gilles Deleuze: Vitalism and multiplicity. London: Pluto Press.

Samaniego, A. R. De. (2015). Las horas bellas_Escritos sobre cine (The Beautiful Hours-Writings on Film). Madrid: AbadaEditores.

Tarkovsky, A. (1987). Sculpting in time. Texas: UTP. 